\title{
Yellow Emission Obtained by Combination of Broadband Emission and Multi-Peak Emission in Garnet Structure $\mathrm{Na}_{2} \mathrm{YMg}_{2} \mathrm{~V}_{3} \mathrm{O}_{12}$ : $\mathrm{Dy}^{3+}$ Phosphor
}

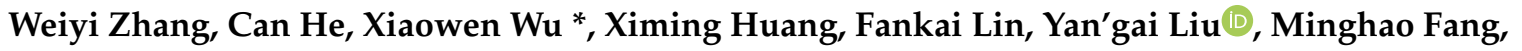 \\ Xin Min and Zhaohui Huang * \\ Beijing Key Laboratory of Materials Utilization of Nonmetallic Minerals and Solid Wastes, National Laboratory \\ of Mineral Materials, School of Materials Science and Technology, China University of Geosciences, \\ Beijing 100083, China; zhangweiyi1993@163.com (W.Z.); hecan1211@163.com (C.H.); \\ xmhuang1995@163.com (X.H.); linfankai85@163.com (F.L.); liuyang@cugb.edu.cn (Y.L.); fmh@cugb.edu.cn (M.F.); \\ minxin4686@126.com (X.M.) \\ * Correspondence: xwwu@cugb.edu.cn (X.W.); huang118@cugb.edu.cn (Z.H.); Tel.: +86-13810536569 (X.W.); \\ $+86-13520265868$ (Z.H.)
}

Academic Editor: Stephane Jobic

Received: 26 December 2019; Accepted: 24 January 2020; Published: 27 January 2020

\begin{abstract}
The fabrication and luminescent performance of novel phosphors $\mathrm{Na}_{2} \mathrm{YMg}_{2} \mathrm{~V}_{3} \mathrm{O}_{12}$ : $\mathrm{Dy}{ }^{3+}$ were investigated by a conventional solid-state reaction method. Under near-UV light, the $\mathrm{Na}_{2} \mathrm{YMg}_{2} \mathrm{~V}_{3} \mathrm{O}_{12}$ host self-activated and released a broad emission band $(400-700 \mathrm{~nm}$, with a peak at $524 \mathrm{~nm})$ ascribable to charge transfer in the $\left(\mathrm{VO}_{4}\right)^{3-}$ groups. Meanwhile, the $\mathrm{Na}_{2} \mathrm{YMg}_{2} \mathrm{~V}_{3} \mathrm{O}_{12}: \mathrm{Dy}^{3+}$ phosphors emitted bright yellow light within both the broad emission band of the $\left(\mathrm{VO}_{4}\right)^{3-}$ groups and the sharp peaks of the $\mathrm{Dy}^{3+}$ ions at 490,582 , and $663 \mathrm{~nm}$ at a quenching concentration of 0.03 mol. The emission of the as-prepared $\mathrm{Na}_{2} \mathrm{YMg}_{2} \mathrm{~V}_{3} \mathrm{O}_{12}: \mathrm{Dy}^{3+}$ phosphors remained stable at high temperatures. The obtained phosphors, commercial $\mathrm{Y}_{2} \mathrm{O}_{3}: \mathrm{Eu}^{3+}$ red phosphors, and $\mathrm{BaMgAl}_{10} \mathrm{O}_{17}: \mathrm{Eu}^{2+}$ blue phosphors were packed into a white light-emitting diode (WLED) device with a near-UV chip. The designed WLED emitted bright white light with good chromaticity coordinates $(0.331,0.361)$, satisfactory color rendering index (80.2), and proper correlation to a color temperature (7364 K). These results indicate the potential utility of $\mathrm{Na}_{2} \mathrm{YMg}_{2} \mathrm{~V}_{3} \mathrm{O}_{12}: \mathrm{Dy}^{3+}$ phosphor as a yellow-emitting phosphor in solid-state illumination.
\end{abstract}

Keywords: $\mathrm{Na}_{2} \mathrm{YMg}_{2} \mathrm{~V}_{3} \mathrm{O}_{12}: \mathrm{Dy}^{3+}$; yellow emitting; luminescence; WLED

\section{Introduction}

For several years, phosphor-converted white light-emitting diodes (pc-WLEDs) have been recognized as the most promising replacements of traditional incandescent and fluorescence lamps [1-5]. These solid-state light sources deliver high luminescence efficiency and an excellent operation lifetime $(>10,000 \mathrm{~h}$ ) while conserving energy and lowering the pollution risk. Most commercial pc-WLEDs are obtained by two methods [6,7]. One method generates white light by combining yellow phosphors with blue LED chips, such as the yellow phosphor YAG: $\mathrm{Ce}^{3+}[8,9]$. However, the absence of the red-emitting component reduces the quality of the white light, yielding poor color reproduction and a low color rendering index $\left(R_{a}\right)$ [10]. The other method stimulates blue, green, and red (RGB) phosphors by violet or ultraviolet light LEDs [11]. Although this method improves the $R_{a}$ and can tune the correlated color temperature (CCT), the emission efficiency is limited by reabsorption among the different phosphors [1,12]. The different thermal stabilities and ageing rates of the various phosphors also restrict their applications in WLEDs [13]. Therefore, high-performance single-phased 
phosphors that can be excited by ultraviolet (UV) or near-UV (n-UV) light are urgently needed [14-16]. A single-host white-emitting phosphor must usually have a broad emission peak or multiple emission peaks in the visible region. Therefore, searching for new broadband emission or multi-peak emission phosphors is significant for improving the color stability and service life of WLEDs excited by UV or n-UV light $[17,18]$.

In recent decades, the rare earth luminescent materials have been used in many fields, such as lighting, photosynthesis enhancement, and photodynamic activation for cancer treatments [19-21]. Broad emission peaks or multiple emission peaks in the visible region facilitate white light emission with appropriate $\mathrm{R}_{\mathrm{a}}$ and CCT values [22-24]. Vanadate composed of $\mathrm{VO}_{4}{ }^{3-}$ tetrahedrons is an important non-rare earth ion-doped luminescent material displaying broadband emission, excellent luminous efficiency, and good chemical stability $[25,26]$. For example, $\mathrm{A}_{3}\left(\mathrm{VO}_{4}\right)_{2}(\mathrm{~A}=\mathrm{Mg}, \mathrm{Sr}, \mathrm{Ba})$ phosphors yield intense charge transfer (CT) absorption bands in the n-UV region and broad emission bands covering $400-700 \mathrm{~nm}$. Further studies have reported that when doped with rare earth ions, vanadate is a good host material that enhances the emission efficiency of phosphors $[27,28]$. Guo et al. reported that $\mathrm{Eu}^{3+}$-activated $\mathrm{Ba}_{2} \mathrm{BiV}_{3} \mathrm{O}_{11}$ phosphors are promising candidates for red-emitting phosphors in WLEDs, as they efficiently convert UV light from $394 \mathrm{~nm}$ onwards into red light [29]. Bright orange-red emission has been obtained by doping $\mathrm{Sm}^{3+}$ in $\mathrm{NaSrVO}_{4}$ phosphor under n-UV light excitation [30]. Song et al. [17] studied self-activated $\mathrm{Na}_{2} \mathrm{YMg}_{2} \mathrm{~V}_{3} \mathrm{O}_{12}$ vanadate phosphors, and reported a broad emission band of $400-700 \mathrm{~nm}$ centered at $520 \mathrm{~nm}$. However, the red emission intensity was relatively low, below the requirements of white light emission. $\mathrm{Dy}^{3+}$ doping should broaden the emission band of $\mathrm{Na}_{2} \mathrm{YMg}_{2} \mathrm{~V}_{3} \mathrm{O}_{12}$ phosphors.

In this work, a series of yellow-emitting $\mathrm{Na}_{2} \mathrm{YMg}_{2} \mathrm{~V}_{3} \mathrm{O}_{12}$ : $\mathrm{Dy}^{3+}$ phosphors was prepared by a conventional high-temperature solid-state method. The phase purities, micromorphologies, luminescence properties, and decay times of the as-prepared $\mathrm{Na}_{2} \mathrm{YMg}_{2} \mathrm{~V}_{3} \mathrm{O}_{12}$ : $\mathrm{Dy}^{3+}$ phosphors were studied in detail. The suitability of the yellow-emitting phosphors for indoor illumination was demonstrated in a WLED device incorporating the developed phosphors.

\section{Results and Discussion}

The phase compositions and crystal structures of the as-prepared powder samples were characterized at room temperature. The XRD patterns of $\mathrm{Na}_{2} \mathrm{YMg}_{2} \mathrm{~V}_{3} \mathrm{O}_{12}: x \mathrm{Dy}^{3+}(x=0,0.005$, $0.01,0.03,0.05,0.07)$ samples exhibited main peaks at $17.5^{\circ}, 20.3^{\circ}, 28.8^{\circ}, 32.3^{\circ}, 33.9^{\circ}, 35.5^{\circ}, 36.9^{\circ}, 51.0^{\circ}$, $53.2^{\circ}$, and 55.4 (Figure 1a), corresponding, respectively, to the (2 111$),(220),(400),(420),(332),(4$ 2 2), (4 31 1), (4 44 ), (6 4 0), and (6 4 2) facets of a single garnet structure with a cubic Ia3d (No. 230) space group. All diffraction peaks of the $\mathrm{Na}_{2} \mathrm{YMg}_{2} \mathrm{~V}_{3} \mathrm{O}_{12}: \mathrm{Dy}^{3+}$ samples were well matched with the standard profile (PDF No.49-0412), confirming that doping with $\mathrm{Y}^{3+}$ ions did not significantly affect the crystalline structure of $\mathrm{Na}_{2} \mathrm{YMg}_{2} \mathrm{~V}_{3} \mathrm{O}_{12}$.

Figure $1 \mathrm{~b}$ shows the spatial structure of the unit cell of the garnet-structured $\mathrm{Na}_{2} \mathrm{YMg}_{2} \mathrm{~V}_{3} \mathrm{O}_{12}$. As implied, the A sites were occupied by alkaline metal ions $\mathrm{Na}^{+}$and rare earth ions $\mathrm{Y}^{3+}$, which were coordinated with eight oxygen $\mathrm{O}^{2-}$ ions to form a dodecahedron with $\mathrm{D}_{2}$ symmetry (without an inverse center). The alkaline-earth metal $\mathrm{Mg}^{2+}$ ions located in the octahedral sites B bonded with six oxygen atoms, and the metal ion $\mathrm{V}^{5+}$ (in $\mathrm{VO}_{4}{ }^{3-}$ ) occupied the $\mathrm{T}_{\mathrm{d}}$ sites and were surrounded by four $\mathrm{O}^{2-}$ ions. As $\mathrm{Y}^{3+}$ and $\mathrm{Dy}^{3+}$ have similar cationic radii and the same valence, the $\mathrm{Y}^{3+}$ ions in the host lattice were easily replaced by $\mathrm{Dy}^{3+}$ ions with no structural transformation. The XRD patterns of $\mathrm{Na}_{2} \mathrm{YMg}_{2} \mathrm{~V}_{3} \mathrm{O}_{12}: \mathrm{Dy}^{3+}$ match those of the standard card, further confirming that the Dy ${ }^{3+}$ ions doped in the $\mathrm{Na}_{2} \mathrm{YMg}_{2} \mathrm{~V}_{3} \mathrm{O}_{12}$ host had replaced the $\mathrm{Y}^{3+}$ sites.

The microscopic morphology, particle size, and grain shape of a phosphor are important factors in applications. Field emission scanning electron microscopy (FESEM) images of the $\mathrm{Na}_{2} \mathrm{YMg}_{2} \mathrm{~V}_{3} \mathrm{O}_{12}: 0.03 \mathrm{Dy}^{3+}$ sample confirmed that all particles were irregular oblate spheres with an average particle size of $1 \mu \mathrm{m}$ (Figure 1c). The spherical morphology was similar to that of commercial YAG: $\mathrm{Ce}^{3+}$ phosphor, which possesses the same garnet structure. The average particle size 
of the prepared phosphor was also similar to that of commercial phosphors. This size may enhance the dispersion and transparency of phosphors in the glue when packaging with the WLEDs.

(a)

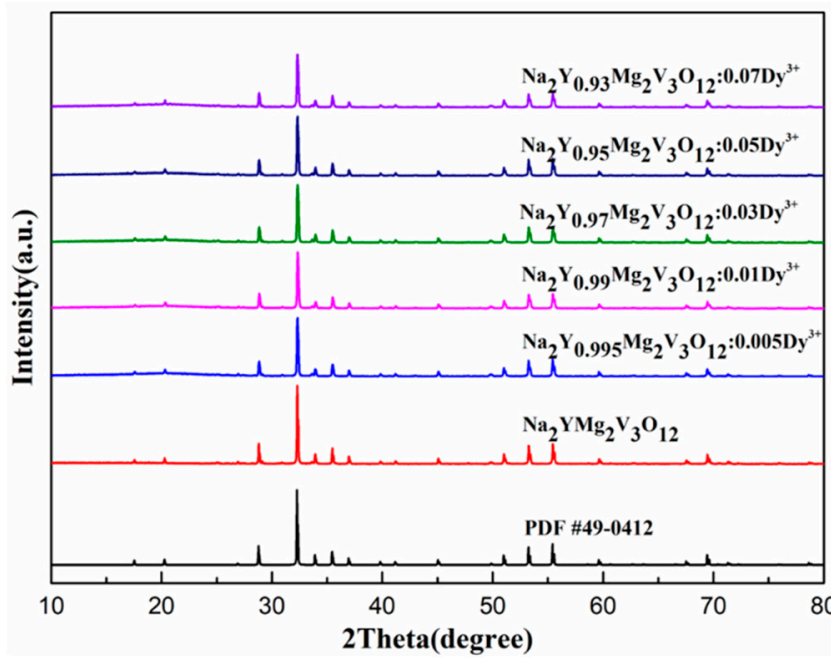

(b)

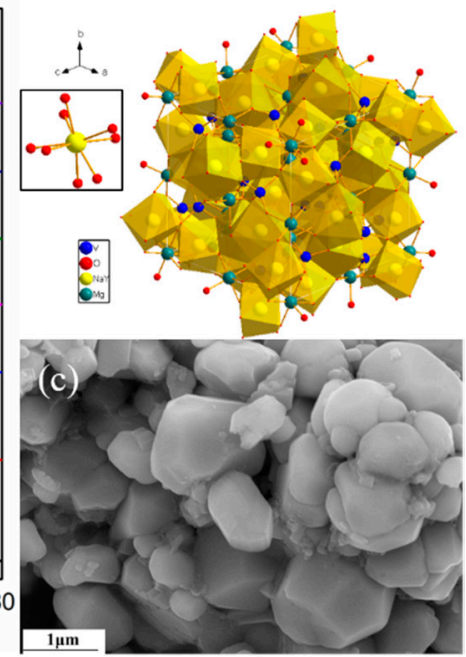

Figure 1. (a) XRD patterns of $\mathrm{Na}_{2} \mathrm{YMg}_{2} \mathrm{~V}_{3} \mathrm{O}_{12}: \mathrm{Dy}^{3+}$ phosphors and the standard profile (Pdf NO. 49-0412), (b) schematic of the crystal structure of $\mathrm{Na}_{2} \mathrm{YMg}_{2} \mathrm{~V}_{3} \mathrm{O}_{12}$, and (c) FESEM micrograph of the $\mathrm{Na}_{2} \mathrm{YMg}_{2} \mathrm{~V}_{3} \mathrm{O}_{12}: 0.03 \mathrm{Dy}^{3+}$ phosphor.

The photoluminescence (PL) and PL emission (PLE) spectra of the undoped $\mathrm{Na}_{2} \mathrm{YMg}_{2} \mathrm{~V}_{3} \mathrm{O}_{12}$ sample are presented in Figure $2 \mathrm{a}-\mathrm{c}$. $\mathrm{Na}_{2} \mathrm{YMg}_{2} \mathrm{~V}_{3} \mathrm{O}_{12}$ shows a broad absorption band of $250-400 \mathrm{~nm}$, matching the absorption of near-UV chips in WLEDs. When excited at $289 \mathrm{~nm}$ and $365 \mathrm{~nm}$, the as-prepared particles also emitted a broad emission band, ranging from 400 to $700 \mathrm{~nm}$ with a maximum at $524 \mathrm{~nm}$. This emission was attributed to the CT of an electron from the $2 p$ orbital of oxygen to the vacant $3 \mathrm{~d}$ orbital of $\mathrm{V}^{5+}$ in the tetrahedral $\left(\mathrm{VO}_{4}\right)^{3-}$ groups [31,32]. The emission band centered at $524 \mathrm{~nm}$ was decomposed into two sub-bands by Gaussian peak separation, one centered at $289 \mathrm{~nm}$ $(4.30 \mathrm{eV})$, the other at $365 \mathrm{~nm}(3.41 \mathrm{eV})$ [33]. As shown in Figure $2 \mathrm{~d}$, the $\left(\mathrm{VO}_{4}\right)^{3-}$ group has a ground state ${ }^{1} \mathrm{~A}_{1}$ and excited states ${ }^{1} \mathrm{~T}_{1},{ }^{1} \mathrm{~T}_{2},{ }^{3} \mathrm{~T}_{1}$, and ${ }^{3} \mathrm{~T}_{2}$. The decomposed emission sub-bands were attributed to ${ }^{3} \mathrm{~T}_{2} \rightarrow{ }^{1} \mathrm{~A}_{1}(\mathrm{Em} 1=512 \mathrm{~nm}(2.43 \mathrm{eV}))$ and ${ }^{3} \mathrm{~T}_{1} \rightarrow{ }^{1} \mathrm{~A}_{1}(\mathrm{Em} 2=571 \mathrm{~nm}(2.18 \mathrm{eV}))$ transitions of the $\left(\mathrm{VO}_{4}\right)^{3-}$ groups, respectively. The excitation band was also composed of two sub-bands, which were assigned to the ${ }^{1} \mathrm{~A}_{1} \rightarrow{ }^{1} \mathrm{~T}_{2}(\mathrm{Ex} 1=4.30 \mathrm{eV})$ and ${ }^{1} \mathrm{~A}_{1} \rightarrow{ }^{1} \mathrm{~T}_{1}(\mathrm{Ex} 2=3.41 \mathrm{eV})$ transitions of the $\left(\mathrm{VO}_{4}\right)^{3-}$ groups. 

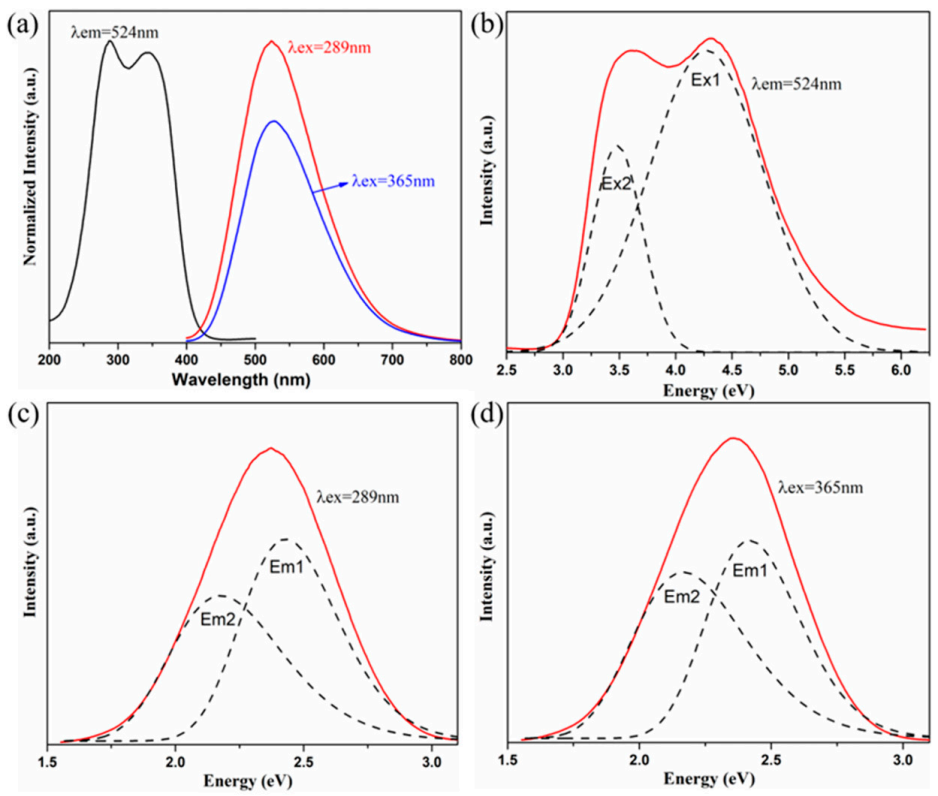

(e)

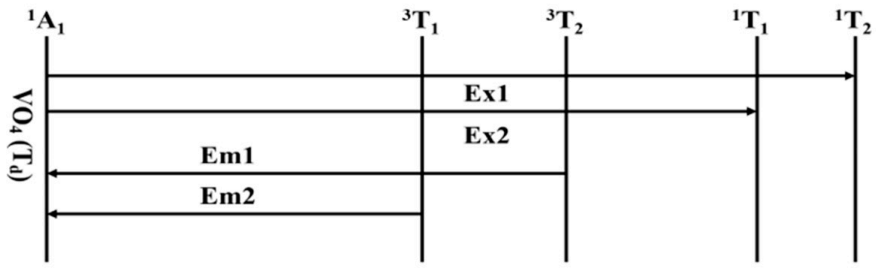

Figure 2. (a) Photoluminescence (PL) and PL emission (PLE) spectra of the $\mathrm{Na}_{2} \mathrm{YMg}_{2} \mathrm{~V}_{3} \mathrm{O}_{12}$ samples, (b), (c), and (d) PLE and PL spectra of the samples after Gaussian peak separation. (e) Schematic of the excitation and emission processes of $\left(\mathrm{VO}_{4}\right)^{3-}$ tetrahedrons in vanadate phosphor.

Figure 3a shows the PLE $\left(\lambda_{\mathrm{em}}=582 \mathrm{~nm}\right)$ and PL $\left(\lambda_{\mathrm{ex}}=289\right.$ and $\left.365 \mathrm{~nm}\right)$ spectra of the $\mathrm{Na}_{2} \mathrm{YMg}_{2} \mathrm{~V}_{3} \mathrm{O}_{12}: 0.03 \mathrm{Dy}^{3+}$ phosphors at room temperature. The broad emission band at $524 \mathrm{~nm}$ was assigned to the CT transitions of the $\left(\mathrm{VO}_{4}\right)^{3-}$ groups, and the emission peaks at 490, 582, and $663 \mathrm{~nm}$ were, respectively, attributed to ${ }^{4} \mathrm{~F}_{9 / 2} \rightarrow{ }^{6} \mathrm{H}_{15 / 2},{ }^{4} \mathrm{~F}_{9 / 2} \rightarrow{ }^{6} \mathrm{H}_{13 / 2}$, and ${ }^{4} \mathrm{~F}_{9 / 2} \rightarrow{ }^{6} \mathrm{H}_{11 / 2}$ transitions of Dy ${ }^{3+}$. Under excitation at $289 \mathrm{~nm}$ and $365 \mathrm{~nm}$, the intensity ratios of the $\left(\mathrm{VO}_{4}\right)^{3-}$ and $\mathrm{Dy}^{3+}$ emissions changed because the excitation pathways of $\mathrm{Dy}^{3+}$ luminescence depend on the excitation wavelength. When excited at $289 \mathrm{~nm}$ and $365 \mathrm{~nm}$, the $\mathrm{Dy}^{3+}$ emission was mainly caused by Dy-O CT and by energy transfer from the absorption of V-O CT, respectively [12,34]. Monitoring the phosphor emission under $582 \mathrm{~nm}$, the broad excitation band from 250 to $400 \mathrm{~nm}$ (which peaks at two sites: $289 \mathrm{~nm}$ and $365 \mathrm{~nm}$ ) resembles the excitation spectrum of non-doped $\mathrm{Na}_{2} \mathrm{YMg}_{2} \mathrm{~V}_{3} \mathrm{O}_{12}$. This may have resulted from the energy transfer behavior from $\mathrm{Na}_{2} \mathrm{YMg}_{2} \mathrm{~V}_{3} \mathrm{O}_{12}$ to $\mathrm{Dy}^{3+}$ ions, which completely overlaps the excitation spectrum of $\mathrm{Na}_{2} \mathrm{YMg}_{2} \mathrm{~V}_{3} \mathrm{O}_{12}$ to $\mathrm{Dy}^{3+}$. The broad excitation spectrum indicates that the $\mathrm{Na}_{2} \mathrm{YMg}_{2} \mathrm{~V}_{3} \mathrm{O}_{12}: \mathrm{Dy}^{3+}$ sample can be efficiently excited under n-UV light, and can be well matched with n-UV LED chips.

The PL spectra of $\mathrm{Na}_{2} \mathrm{YMg}_{2} \mathrm{~V}_{3} \mathrm{O}_{12}: x \mathrm{Dy}^{3+}(x=0,0.005,0.01,0.03,0.05,0.07)$ samples with different doping concentrations are shown in Figure $3 b, c$. As the $\mathrm{Dy}^{3+}$ concentration increased, the intensities of the emission peaks increased to a maximum at $x=0.03$, and then decreased under the concentration quenching effect [35]. To investigate the cause of concentration quenching, the interaction type between two excitations was calculated by the following formula:

$$
\frac{I}{x}=\frac{k}{1+\beta x^{Q / 3}}
$$


where $k$ and $\beta$ are constants, $I$ is the emission intensity, and $Q$ represents the interaction type. When $Q$ is $3,6,8$, and 10, the interactions are exchange, dipole-dipole, dipole-quadrupole, and quadrupole-quadrupole interactions, respectively. The $Q$ value was obtained by linear fitting of the relationship between $\lg (I / x)$ and $\lg (x)$. When the phosphors were excited at 289 and $365 \mathrm{~nm}$, the slopes $(-Q / 3)$ were determined as -0.995 and -0.968 , respectively (Figure $3 \mathrm{~d}$ ). Both $Q$ values were close to the theoretical value of 3.0, indicating that at higher concentrations, the intensity of the $\mathrm{Na}_{2} \mathrm{YMg}_{2} \mathrm{~V}_{3} \mathrm{O}_{12}: \mathrm{Dy}^{3+}$ phosphors was quenched by exchange interactions. The excitation spectra of $\mathrm{Na}_{2} \mathrm{YMg}_{2} \mathrm{~V}_{3} \mathrm{O}_{12}: \mathrm{xDy}^{3+}$ monitored at $582 \mathrm{~nm}$ were also optimized at $x=0.03$ (Figure 3e). The CIE (International Commission on illumination) chromaticity coordinates of the $\mathrm{Na}_{2} \mathrm{YMg}_{2} \mathrm{~V}_{3} \mathrm{O}_{12}: 0.03 \mathrm{Dy}^{3+}$ sample were determined as $(0.357,0.461)$ (Figure $3 \mathrm{f})$. The yellow light emission was the combination of the self-activated emission of the $\mathrm{Na}_{2} \mathrm{YMg}_{2} \mathrm{~V}_{3} \mathrm{O}_{12}$ host with the dominant $4 \mathrm{f}-4 \mathrm{f}$ transitions of the $\mathrm{Dy}^{3+}$ ion [36].
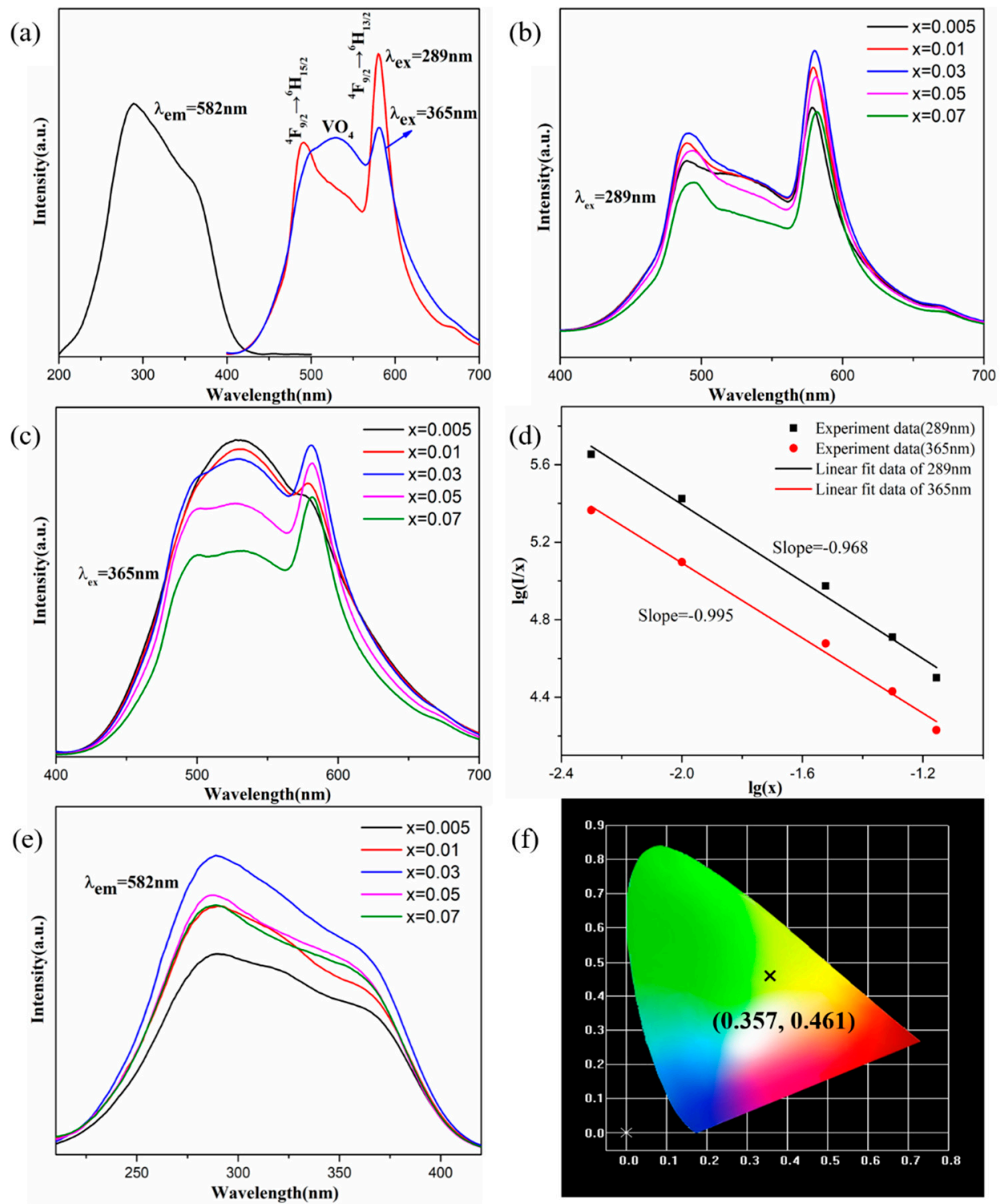

Figure 3. (a) PLE and PL spectra of the $\mathrm{Na}_{2} \mathrm{YMg}_{2} \mathrm{~V}_{3} \mathrm{O}_{12}: 0.03 \mathrm{Dy}^{3+}$ sample. Emission spectra at (b) $\lambda_{\mathrm{ex}}=289 \mathrm{~nm}$ and (c) $\lambda_{\mathrm{ex}}=365 \mathrm{~nm}$ for different concentrations of $\mathrm{Dy}^{3+}$ in $\mathrm{Na}_{2} \mathrm{YMg}_{2} \mathrm{~V}_{3} \mathrm{O}_{12}: x \mathrm{Dy}^{3+}$. (d) Linear fitting data of $\lg (I / x)$ versus $\lg (x)$ for the $\mathrm{Na}_{2} \mathrm{YMg}_{2} \mathrm{~V}_{3} \mathrm{O}_{12}: x \mathrm{Dy}^{3+}$ phosphors. (e) Excitation spectra $\left(\lambda_{\mathrm{em}}=582 \mathrm{~nm}\right)$ of $\mathrm{Na}_{2} \mathrm{YMg}_{2} \mathrm{~V}_{3} \mathrm{O}_{12}: x \mathrm{Dy}^{3+}$. (f) $\mathrm{CIE}$ chromaticity coordinates of the $\mathrm{Na}_{2} \mathrm{YMg}_{2} \mathrm{~V}_{3} \mathrm{O}_{12}: 0.03 \mathrm{Dy}^{3+}$ sample. 
To understand the behaviors of the synthesized compounds, the $\mathrm{Na}_{2} \mathrm{YMg}_{2} \mathrm{~V}_{3} \mathrm{O}_{12}$ : $\mathrm{xDy}{ }^{3+}$ phosphors were excited at 289 and $365 \mathrm{~nm}$, and their PL decay curves were recorded at $582 \mathrm{~nm}$. The results are shown in Figure 4. The decay curves of $\mathrm{Na}_{2} \mathrm{YMg}_{2} \mathrm{~V}_{3} \mathrm{O}_{12}: \mathrm{xDy}^{3+}$ were well fitted to the following exponential function [37]:

$$
I_{t}=A e^{-\frac{t}{\tau}}+I_{0}
$$

where $I_{t}$ and $I_{0}$ are the emission intensities at time $t$ and the initial time, respectively, and $A$ is a constant. $\tau$ determines the decay time. The average lifetimes of the $\mathrm{Na}_{2} \mathrm{YMg}_{2} \mathrm{~V}_{3} \mathrm{O}_{12}: x \mathrm{Dy}^{3+}$ phosphors with $x=0$, $0.005,0.01,0.03,0.05$, and 0.07 were determined as $1.60,1.58,1.54,1.48,1.42$, and $1.44 \mu$, respectively, at $\lambda_{\mathrm{ex}}=289 \mathrm{~nm}$, and as $1.53,1.52,1.49,1.50,1.41$, and $1.40 \mu \mathrm{s}$, respectively, at $\lambda_{\mathrm{ex}}=365 \mathrm{~nm}$. The PL lifetimes of the $\mathrm{Na}_{2} \mathrm{YMg}_{2} \mathrm{~V}_{3} \mathrm{O}_{12}: x \mathrm{Dy}^{3+}$ were similar under both excitation wavelengths, possibly reflecting the similar energy transfer behaviors between the vanadate host and $\mathrm{Dy}^{3+}$.

(a)

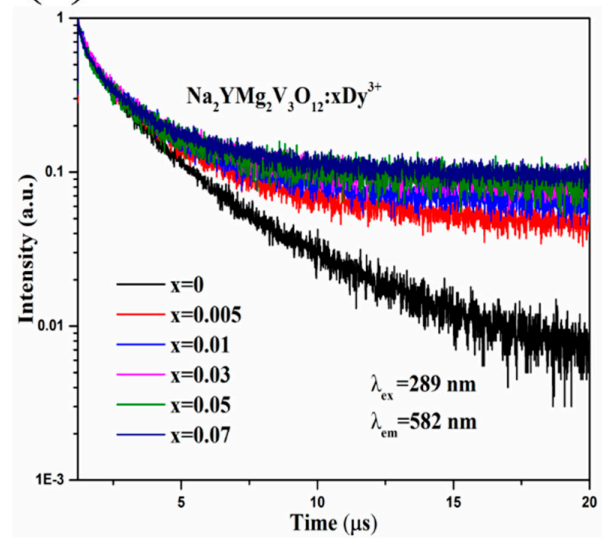

(b)

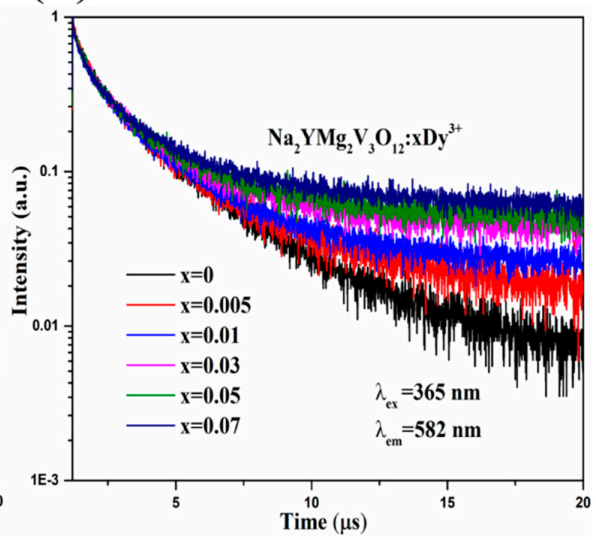

Figure 4. Decay curves of $\mathrm{Na}_{2} \mathrm{YMg}_{2} \mathrm{~V}_{3} \mathrm{O}_{12}: x \mathrm{Dy}^{3+}$ with different concentrations of $\mathrm{Dy}^{3}$ excited at (a) $\lambda_{\mathrm{ex}}=289 \mathrm{~nm}$ and $(\mathbf{b}) \lambda_{\mathrm{ex}}=365 \mathrm{~nm},\left(\lambda_{\mathrm{em}}=582 \mathrm{~nm}\right)$.

High thermal resistance of phosphors is very important for practical applications in solid-state lighting, as it ensures high optical performance of the WLED device. The thermal quenching performance of $\mathrm{Na}_{2} \mathrm{YMg}_{2} \mathrm{~V}_{3} \mathrm{O}_{12}: 0.03 \mathrm{Dy}^{3+}$ phosphor was assessed from the temperature-dependent emission spectra under excitation at 289 and $365 \mathrm{~nm}$. As shown in Figure 5a,c, the emission intensity reduced smoothly as the temperature increased, because the probability of non-radiative transitions increases at higher temperatures. As shown in the insets of Figure 5a,c, the PL integral intensities at $100{ }^{\circ} \mathrm{C}$ were $61.6 \%\left(\lambda_{\mathrm{ex}}=289 \mathrm{~nm}\right)$ and $61.48 \%\left(\lambda_{\mathrm{ex}}=365 \mathrm{~nm}\right)$ of their room temperature intensities. However, the emission positions in the temperature-dependent emission spectra were relatively robust to temperature changes.

To further investigate the thermal stability of this phosphor, the activation energy $(\Delta E)$ of $\mathrm{Na}_{2} \mathrm{YMg}_{2} \mathrm{~V}_{3} \mathrm{O}_{12}: 0.03 \mathrm{Dy}^{3+}$ was calculated by the Arrhenius equation [38]:

$$
I(T)=\frac{I_{0}}{1+c e^{-\frac{\Delta E}{k T}}}
$$

where $I_{0}$ is the emission intensity of the phosphor at room temperature, $I(T)$ is the temperature-dependent intensity, $c$ is a constant, and $k$ is the Boltzmann constant $\left(8.629 \times 10^{-5} \mathrm{eV} \mathrm{K}^{-1}\right)$. From the slopes of the $\ln \left[I_{0} / I(\mathrm{~T})-1\right]$ versus $1 / k T$ plots (Figure $5 \mathrm{~b}, \mathrm{~d}$ ), which were well fitted to Equation (3), the $\Delta E$ s were determined as 0.21 and $0.26 \mathrm{eV}$ under excitation at 289 and $365 \mathrm{~nm}$, respectively. Table 1 compares the CIE chromaticity coordinates, CCT and lifetimes of $\mathrm{Na}_{2} \mathrm{YMg}_{2} \mathrm{~V}_{3} \mathrm{O}_{12}: 0.03 \mathrm{Dy}{ }^{3+}$, and other $\mathrm{Dy}^{3+}$-doped phosphors [39-41]. The obtained $\mathrm{Na}_{2} \mathrm{YMg}_{2} \mathrm{~V}_{3} \mathrm{O}_{12}: \mathrm{Dy}^{3+}$ phosphors presented relatively high thermal stability and are potentially applicable to WLEDs. 
Table 1. Comparison of CIE chromaticity coordinates $(x, y)$, correlated color temperature (CCT) (K), and lifetimes ( $\mu$ s) of $\mathrm{Dy}^{3+}$-doped phosphors.

\begin{tabular}{|c|c|c|c|c|}
\hline Sample & $(x, y)$ & CCT & Lifetimes & Reference \\
\hline $\mathrm{Na}_{2} \mathrm{YMg}_{2} \mathrm{~V}_{3} \mathrm{O}_{12}: \mathrm{Dy}^{3+}$ & $(0.357,0.461)$ & 4288 & 1.50 & Present work \\
\hline $\mathrm{Sr}_{3} \mathrm{Y}_{2}\left(\mathrm{BO}_{3}\right)_{4}: \mathrm{Dy}^{3+}$ & $(0.300,0.314)$ & 5896 & - & [42] \\
\hline $\mathrm{KBaY}(\mathrm{MoO} 4)_{3}: \mathrm{Dy}^{3+}$ & $(0.431,0.457)$ & 3988 & 0.125 & [43] \\
\hline $\mathrm{Na}_{3} \mathrm{Gd}\left(\mathrm{VO}_{4}\right)_{2}: \mathrm{Dy}^{3+}$ & $(0.664,0.335)$ & - & 0.234 & [22] \\
\hline $\mathrm{Ca}_{3} \mathrm{TeO}_{6}: \mathrm{Dy}^{3+}$ & $(0.417,0.460)$ & 3730 & 0.506 & [35] \\
\hline $\mathrm{NaLa}\left(\mathrm{PO}_{3}\right)_{4}: \mathrm{Dy}^{3+}$ & $(0.292,0.336)$ & - & 0.78 & [44] \\
\hline $\mathrm{NaCaPO}_{4}: \mathrm{Dy}^{3+}$ & $(0.32,0.37)$ & 5962 & 0.604 & [45] \\
\hline
\end{tabular}

(a)

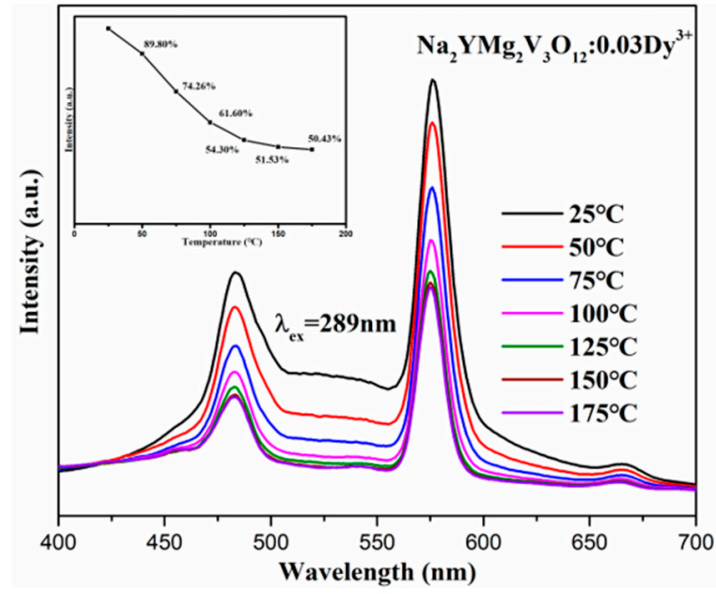

(c)

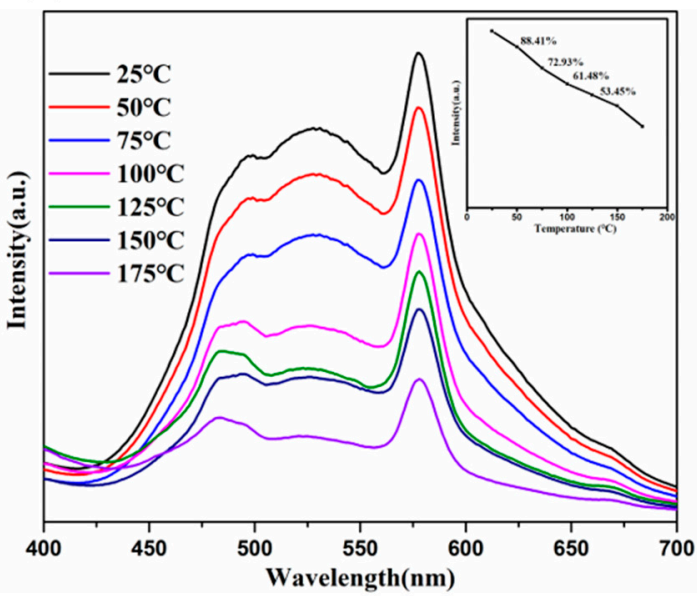

(b)

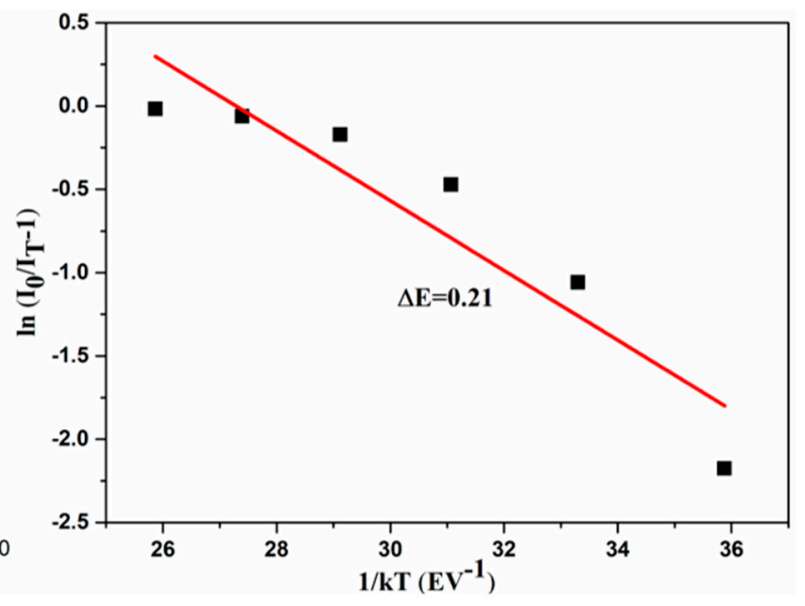

(d)

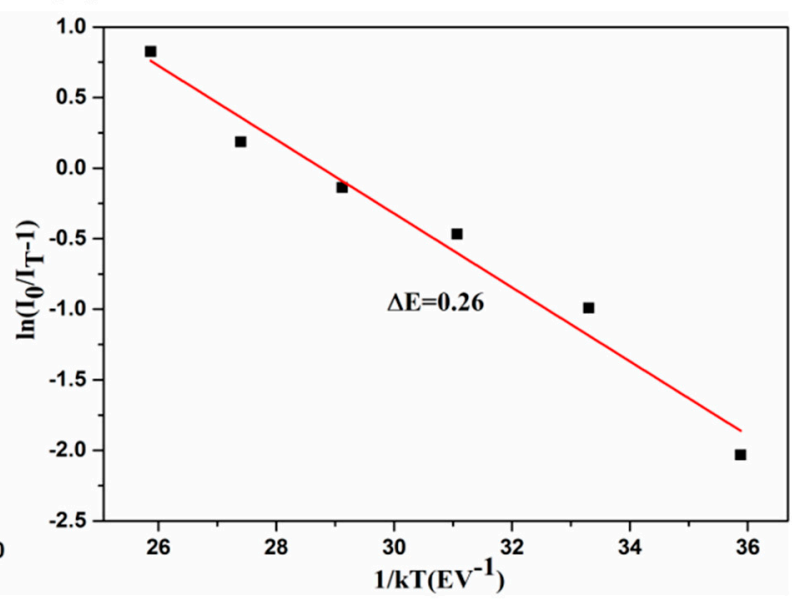

Figure 5. (a,c): PL spectra of the $\mathrm{Na}_{2} \mathrm{YMg}_{2} \mathrm{~V}_{3} \mathrm{O}_{12}: 0.03 \mathrm{Dy}^{3+}$ phosphor at different temperatures $\left(25-175{ }^{\circ} \mathrm{C}\right)$ excited at $\lambda_{\mathrm{ex}}=289$ and $365 \mathrm{~nm}$, respectively. Insets show the PL intensities of $\mathrm{Na}_{2} \mathrm{YMg}_{2} \mathrm{~V}_{3} \mathrm{O}_{12}: 0.03 \mathrm{Dy}^{3+}$ as functions of temperature. (b,d): Linear fitting curves of $\ln \left[I_{0} / I(T)-\right.$ 1] versus $1 / k T$ for the $\mathrm{Na}_{2} \mathrm{YMg}_{2} \mathrm{~V}_{3} \mathrm{O}_{12}: 0.03 \mathrm{Dy}^{3+}$ phosphor excited at 582 and $365 \mathrm{~nm}$, respectively.

To further prove the feasibility of the as-prepared phosphors in solid-state illumination, we designed and packaged WLED devices based on an n-UV chip $(365 \mathrm{~nm})$ and the $\mathrm{Na}_{2} \mathrm{YMg}_{2} \mathrm{~V}_{3} \mathrm{O}_{12}$ : $\mathrm{Dy}^{3+}$ phosphors. To compensate for the color combination imbalance and improve the $\mathrm{R}_{\mathrm{a}}$ of the LEDs, we added small amounts of commercial $\mathrm{Y}_{2} \mathrm{O}_{3}: \mathrm{Eu}^{3+}$ red phosphors and $\mathrm{BaMgAl}_{10} \mathrm{O}_{17}: \mathrm{Eu}^{2+}$ blue phosphors, thereby fabricating a warm white-emitting LED. Figure 6 shows the electroluminescence spectra and 
photographs of the as-fabricated LED devices. Obviously, after adding the red and blue phosphors, the emission light of the LED device changed from yellow to white. The CIE coordinates, $R_{a}$ value, and CCT of the white light generated from the LED device (Figure $6 c$ ) were $(0.331,0.361), 80.2$, and $7364 \mathrm{~K}$, respectively. The CIE chromaticity coordinates of the LED device are also given in Figure 7. The fabricated device yielded a warm white light. The results demonstrate that the as-prepared phosphors are promising yellow-emitting phosphors for indoor solid-state illumination.

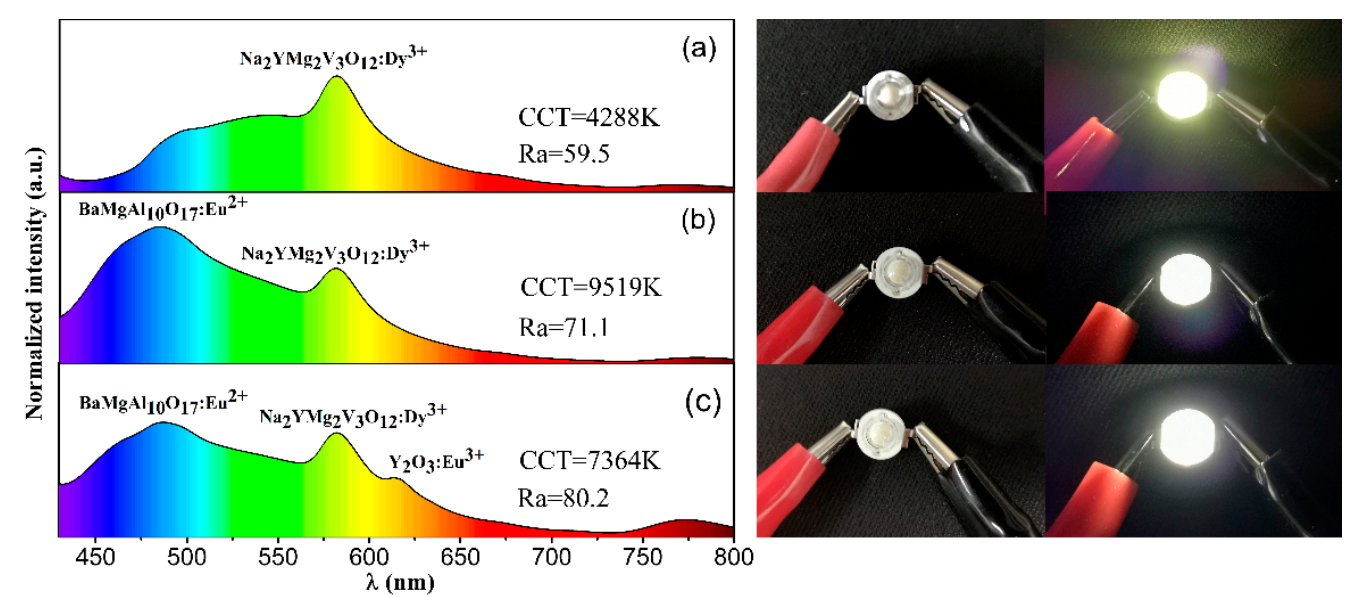

Figure 6. Electroluminescence (EL) spectra (left) and photographs (right) of (a) $\mathrm{Na}_{2} \mathrm{YMg}_{2} \mathrm{~V}_{3} \mathrm{O}_{12}: 0.03 \mathrm{Dy}^{3+}$, (b) $\mathrm{Na}_{2} \mathrm{YMg}_{2} \mathrm{~V}_{3} \mathrm{O}_{12}: 0.03 \mathrm{Dy}^{3+}$ with $\mathrm{BaMgAl}_{10} \mathrm{O}_{17}: \mathrm{Eu}^{2+}$, and (c) $\mathrm{Na}_{2} \mathrm{YMg}_{2} \mathrm{~V}_{3} \mathrm{O}_{12}: 0.03 \mathrm{Dy}^{3+}$ with $\mathrm{BaMgAl}_{10} \mathrm{O}_{17}: \mathrm{Eu}^{2+}$ and $\mathrm{Y}_{2} \mathrm{O}_{3}: \mathrm{Eu}^{3+}$. The samples were incorporated into $365 \mathrm{~nm}$ InGaN LED chips with an injunction current.

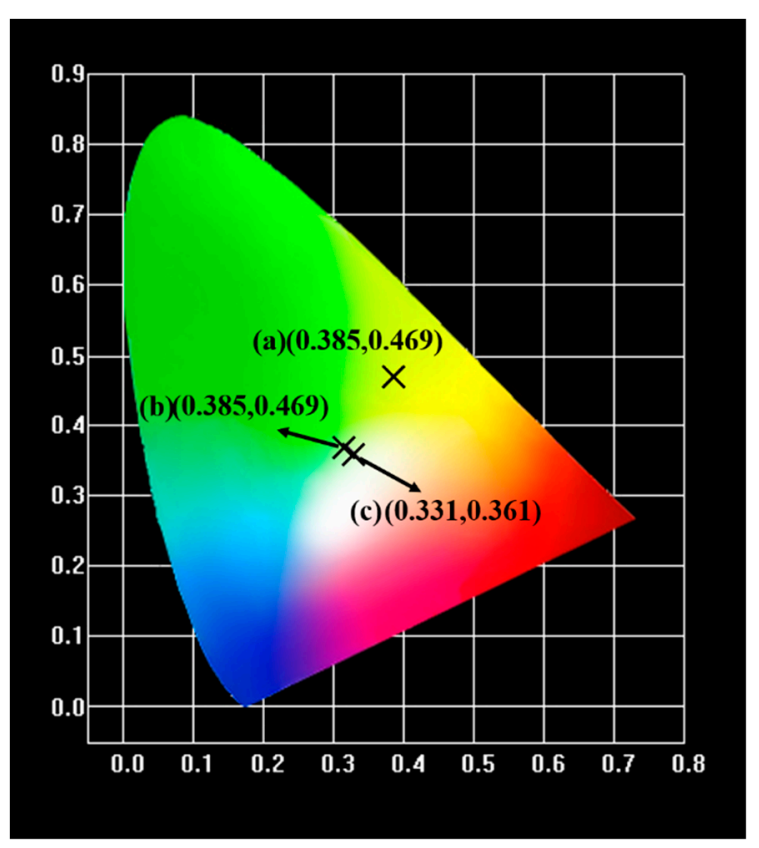

Figure 7. CIE coordinates of LEDs fabricated with (a) $\mathrm{Na}_{2} \mathrm{YMg}_{2} \mathrm{~V}_{3} \mathrm{O}_{12}: 0.03 \mathrm{Dy}^{3+}$, (b) $\mathrm{Na}_{2} \mathrm{YMg}_{2} \mathrm{~V}_{3} \mathrm{O}_{12}: 0.03 \mathrm{Dy}^{3+}$ and $\mathrm{BaMgAl}_{10} \mathrm{O}_{17}: \mathrm{Eu}^{2+}$, and (c) $\mathrm{Na}_{2} \mathrm{YMg}_{2} \mathrm{~V}_{3} \mathrm{O}_{12}: 0.03 \mathrm{Dy}^{3+}$, $\mathrm{BaMgAl}_{10} \mathrm{O}_{17}: \mathrm{Eu}^{2+}$, and $\mathrm{Y}_{2} \mathrm{O}_{3}: \mathrm{Eu}^{3+}$ phosphors.

\section{Materials and Methods}

The $\mathrm{Na}_{2} \mathrm{YMg}_{2} \mathrm{~V}_{3} \mathrm{O}_{12}: \mathrm{xDy}^{3+}(\mathrm{x}=0,0.005,0.01,0.03,0.05,0.07)$ phosphors were prepared through a solid state reaction method. The analytical reagent $\mathrm{Mg}(\mathrm{OH})_{2}$ (average particle size, $\mathrm{d}_{50} \sim 3.798 \mu \mathrm{m}$ ), 
$\mathrm{NaHCO}_{3}\left(\mathrm{~d}_{50} \sim 5.638 \mu \mathrm{m}\right), \mathrm{NH}_{4} \mathrm{VO}_{3}\left(\mathrm{~d}_{50} \sim 160.3 \mu \mathrm{m}\right)$, and high pure rare earth oxides $\mathrm{Y}_{2} \mathrm{O}_{3}(99.99 \%$, $\left.\mathrm{d}_{50} \sim 3.869 \mu \mathrm{m}\right)$ and $\mathrm{Dy}_{2} \mathrm{O}_{3}\left(99.9 \% \mathrm{~d}_{50} \sim 3.990 \mu \mathrm{m}\right)$ were used as raw materials. It is noteworthy that $5 \mathrm{~mol} \%$ excess $\mathrm{NaHCO}_{3}$ was needed to compensate for the volatilization loss. The raw materials were mixed thoroughly in agate mortar for $30 \mathrm{~min}$ and then put into a crucible with a lid. These mixed chemicals were preheated in a muffle furnace at $500^{\circ} \mathrm{C}$ for $6 \mathrm{~h}$, and then heated at $800^{\circ} \mathrm{C}$ for $6 \mathrm{~h}$ in air. After cooling to room temperature naturally, the samples were ground into powders for measurement.

The LED devices were fabricated with the as-prepared $\mathrm{Na}_{2} \mathrm{YMg}_{2} \mathrm{~V}_{3} \mathrm{O}_{12}: 0.03 \mathrm{Dy}^{3+}$ phosphor, commercial $\mathrm{Y}_{2} \mathrm{O}_{3}: \mathrm{Eu}^{3+}$ red phosphors, $\mathrm{BaMgAl}_{10} \mathrm{O}_{17}: \mathrm{Eu}^{2+}$ blue phosphors, and an InGaN chip with a dominant emission at $365 \mathrm{~nm}$ (Shenzhen Looking Long Technology Co., Shenzhen, China). First, the phosphors were thoroughly mixed with organic silica gel. The weight ratio of total phosphors to organic silica gel is about 1:5. The silica gel used to package LED chips needs excellent light transmittance [46], and the light transmittance of the silica gel we chose is $96 \%$ (thickness of $1 \mathrm{~mm}$ ). Then, the surfaces of the InGaN chips were coated with the mixture with an approximate thickness of $0.5 \mathrm{~mm}$. Finally, the chips were dried at $135^{\circ} \mathrm{C}$ for $2 \mathrm{~h}$ and the LED devices was obtained.

The powder X-ray diffractometer (XRD-6000, SHIMADZU, Kyoto, Japan) with $\mathrm{Cu}$ K $\alpha$ radiation $(\lambda=0.15406 \mathrm{~nm})$ was used to measure the phase composition of the as-prepared samples with a $40 \mathrm{kV}$ operating voltage and $30 \mathrm{~mA}$ current. The microscopic morphology of the as-synthesized sample was investigated by a field-emission scanning electron microscope (SEM, Model Zeiss Supra-55, Heidenheim, Germany). The fluorescence spectrophotometer (F-4600, HITACHI, Tokyo, Japan) equipped with a $150 \mathrm{~W}$ Xe lamp as an excitation source was utilized to measure the photoluminescence (PL) and photoluminescence excitation (PLE) spectra at room temperature under $400 \mathrm{~V}$ of operating voltage (Xe lamp). The photoluminescence spectrum of the selected phosphor, which is temperature-dependent, was examined using a computer-controlled electric furnace spectrophotometer (TAP02, Orient KOJI, Tianjin, China). The phosphor powder was heated with a heating rate of $50{ }^{\circ} \mathrm{C} / \mathrm{min}$, and held at each test temperature for $3 \mathrm{~min}$. The PL decay curves were obtained through a spectrofluorometer (TBX-PS; HORIBA Jobin Yvon, Paris, France) monitoring at 593nm under excitations of $289 \mathrm{~nm}$ and $365 \mathrm{~nm}$, respectively. The electroluminescence spectra, CCT, and Ra of the packed LED devices were measured using a UV-vis-near IR spectrophotocolorimeter (PMS-80, Everfine, Hangzhou, China).

\section{Conclusions}

In summary, a series of vanadate phosphors $\mathrm{Na}_{2} \mathrm{YMg}_{2} \mathrm{~V}_{3} \mathrm{O}_{12}$ : $\mathrm{Dy}^{3+}$ was synthesized by the conventional solid-state reaction method at $800{ }^{\circ} \mathrm{C}$ for $6 \mathrm{~h}$. In the XRD analysis, the as-prepared phosphors were found to crystallize in a single garnet structure with a cubic Ia3d (230) space group. When excited by near-UV light, the $\mathrm{Na}_{2} \mathrm{YMg}_{2} \mathrm{~V}_{3} \mathrm{O}_{12}$ host was self-activated and emitted a broad emission band of $400-700 \mathrm{~nm}$ with a peak at $524 \mathrm{~nm}$. This emission was ascribed to CT in the $\left(\mathrm{VO}_{4}\right)^{3-}$ groups. Meanwhile, the $\mathrm{Na}_{2} \mathrm{YMg}_{2} \mathrm{~V}_{3} \mathrm{O}_{12}$ : Dy ${ }^{3+}$ phosphors showed both the broadband luminescence of the $\left(\mathrm{VO}_{4}\right)^{3-}$ groups and the sharp peak emissions of $\mathrm{Dy}^{3+}$ ions, and emitted intense yellow light. The phosphors were also excited by light at 289 and $365 \mathrm{~nm}$, and the optimum $\mathrm{Dy}^{3+}$ concentration was around $0.03 \mathrm{~mol}$. The temperature-dependent emission spectra indicated high thermal stability of the $\mathrm{Na}_{2} \mathrm{YMg}_{2} \mathrm{~V}_{3} \mathrm{O}_{12}$ : Dy ${ }^{3+}$ phosphors. Finally, a WLED device based on n-UV chip, $\mathrm{Na}_{2} \mathrm{YMg}_{2} \mathrm{~V}_{3} \mathrm{O}_{12}: 0.03 \mathrm{Dy}^{3+}, \mathrm{Y}_{2} \mathrm{O}_{3}: \mathrm{Eu}^{3+}$, and $\mathrm{BaMgAl}_{10} \mathrm{O}_{17}: \mathrm{Eu}^{2+}$ presented an intense white light with CIE coordinates, color rendering index, and CCT of $(0.331,0.361), 80.2$, and $7364 \mathrm{~K}$, respectively. These results suggest the suitability of $\mathrm{Na}_{2} \mathrm{YMg}_{2} \mathrm{~V}_{3} \mathrm{O}_{12}$ : Dy $^{3+}$ phosphor as a yellow-emitting phosphor in WLEDs.

Author Contributions: Data curation, X.H.; Formal analysis, C.H. and M.F.; Investigation, F.L. and Y.L.; Methodology, X.M.; Writing-original draft, W.Z.; Writing-review \& editing, X.W. and Z.H. All authors have read and agree to the published version of the manuscript.

Funding: Supported by the Fundamental Research Funds for the Central Universities (Grant No. 2652018325, 2652018321, 2652018320) and the National Key R\&D Program of China (Grant No. 2018YFC190503).

Conflicts of Interest: The authors declare no conflict of interest. 


\section{References}

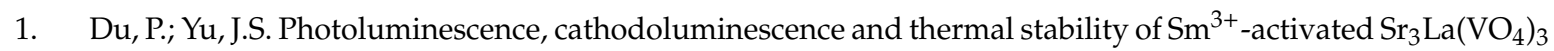
red-emitting phosphors. Luminescence 2017, 32, 1504-1510. [CrossRef]

2. He, C.; Ji, H.; Huang, Z.; Wang, T.; Zhang, X.; Liu, Y.; Fang, M.; Wu, X.; Zhang, J.; Min, X. Red-shifted emission in $\mathrm{Y}_{3} \mathrm{MgSiAl}_{3} \mathrm{O}_{12}: \mathrm{Ce}^{3+}$ garnet phosphor for blue light-pumped white light-emitting diodes. J. Phys. Chem. C 2018, 122, 15659-15665. [CrossRef]

3. Min, X.; Fang, M.; Huang, Z.; Liu, Y.G.; Tang, C.; Wu, X. Synthesis and optical properties of $\operatorname{Pr}^{3+}$-doped $\mathrm{LaMgAl}_{11} \mathrm{O}_{19}$ - $\mathrm{A}$ novel blue converting yellow phosphor for white light emitting diodes. Ceram. Int. 2015, 41, 4238-4242. [CrossRef]

4. Xie, R.-J.; Hirosaki, N. Silicon-based oxynitride and nitride phosphors for white LEDs-A review. Sci. Technol. Adv. Mater. 2007, 8, 588. [CrossRef]

5. Xie, R.-J.; Hirosaki, N.; Suehiro, T.; Xu, F.-F.; Mitomo, M. A simple, efficient synthetic route to $\mathrm{Sr}_{2} \mathrm{Si}_{5} \mathrm{~N}_{8}$ : $\mathrm{Eu}^{2+}$-based red phosphors for white light-emitting diodes. Chem. Mater. 2006, 18, 5578-5583. [CrossRef]

6. Chiang, C.-H.; Fang, Y.-C.; Lin, H.-Y.; Chu, S.-Y. Photoluminescence properties and thermal stability of samarium-doped barium phosphate phosphors. Ceram. Int. 2017, 43, 4353-4356. [CrossRef]

7. Cao, Y.; Ding, J.; Ding, X.; Wang, X.; Wang, Y. Tunable white light of multi-cation-site $\mathrm{Na}_{2} \mathrm{BaCa}_{(}\left(\mathrm{PO}_{4}\right)_{2}: \mathrm{Eu}$, Mn phosphor: Synthesis, structure and PL/CL properties. J. Mater. Chem. C 2017, 5, 1184-1194. [CrossRef]

8. Dang, P.; Liang, S.; Li, G.; Wei, Y.; Cheng, Z.; Lian, H.; Shang, M.; Al Kheraif, A.A.; Lin, J. Full Color Luminescence Tuning in $\mathrm{Bi}^{3+} / \mathrm{Eu}^{3+}$-Doped $\mathrm{LiCa}_{3} \mathrm{MgV}_{3} \mathrm{O}_{12}$ Garnet Phosphors Based on Local Lattice Distortion and Multiple Energy Transfers. Inorg. Chem. 2018, 57, 9251-9259. [CrossRef]

9. Ji, H.; Cho, Y.; Wang, L.; Hirosaki, N.; Molokeev, M.S.; Huang, Z.; Xie, R.-J. Phase formation of $(\mathrm{Y}, \mathrm{Ce})_{2} \mathrm{BaAl}_{4} \mathrm{SiO}_{12}$ yellow microcrystal-glass phosphor for blue LED pumped white lighting. Ceram. Int. 2017, 43, 6425-6429. [CrossRef]

10. Lee, S.H.; Du, P.; Bharat, L.K.; Yu, J.S. Ultraviolet radiation excited strong red-emitting $\mathrm{LaAlO}_{3}: \mathrm{Eu}^{3+}$ nanophosphors: Synthesis and luminescent properties. Ceram. Int. 2017, 43, 4599-4605. [CrossRef]

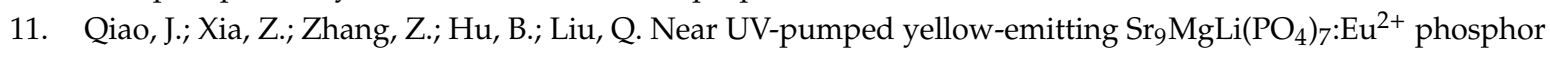
for white-light LEDs. Sci. China Mater. 2018, 61, 985-992. [CrossRef]

12. Liu, S.; Liu, S.; Wang, J.; Sun, P.; Zhong, Y.; Jeong, J.H.; Deng, B.; Yu, R. Preparation and investigation of $\mathrm{Dy}^{3+}$-doped Ca${ }_{9} \mathrm{LiGd}_{2 / 3}\left(\mathrm{PO}_{4}\right)_{7}$ single-phase full-color phosphor. Mater. Res. Bull. 2018, 108, 275-280. [CrossRef]

13. Xia, Z.; Meijerink, A. Ce ${ }^{3+}$-Doped garnet phosphors: Composition modification, luminescence properties and applications. Chem. Soc. Rev. 2017, 46, 275-299. [CrossRef] [PubMed]

14. Huang, C.-H.; Liu, W.-R.; Chen, T.-M. Single-phased white-light phosphors Ca, $\mathrm{Gd}_{(}\left(\mathrm{PO}_{4}\right)_{7}: \mathrm{Eu}^{2+}, \mathrm{Mn}^{2+}$ under near-ultraviolet excitation. J. Phys. Chem. C 2010, 114, 18698-18701. [CrossRef]

15. Miao, S.; Xia, Z.; Zhang, J.; Liu, Q. Increased $\mathrm{Eu}^{2+}$ content and codoping $\mathrm{Mn}^{2+}$ induced tunable full-color emitting phosphor $\mathrm{Ba}_{1.55} \mathrm{Ca}_{0.45} \mathrm{SiO}_{4}: \mathrm{Eu}^{2+}, \mathrm{Mn}^{2+}$. Inorg. Chem. 2014, 53, 10386-10393. [CrossRef]

16. Min, X.; Fang, M.; Huang, Z.; Liu, Y.; Tang, C.; Wu, X. Luminescent properties of white-light-emitting phosphor $\mathrm{LaMgAl}_{11} \mathrm{O}_{19}: \mathrm{Dy}^{3+}$. Mater. Lett. 2014, 125, 140-142. [CrossRef]

17. Song, D.; Guo, C.; Li, T. Luminescence of the self-activated vanadate phosphors $\mathrm{Na}_{2} \operatorname{LnMg}_{2} \mathrm{~V}_{3} \mathrm{O}_{12}(\mathrm{Ln}=\mathrm{Y}$, Gd). Ceram. Int. 2015, 41, 6518-6524. [CrossRef]

18. Zhang, Q.; Hu, Y.; Ju, G.; Zhang, S.; Xue, F. Photoluminescence of a novel $\mathrm{Na}_{3} \mathrm{Y}\left(\mathrm{VO}_{4}\right)_{2}: \mathrm{Eu}^{3+}$ red phosphor for near ultraviolet light emitting diodes application. J. Mater. Sci. Mater. Electron. 2016, 28, 2529-2537. [CrossRef]

19. Chen, W.; Zhang, J. Using nanoparticles to enable simultaneous radiation and photodynamic therapies for cancer treatment. J. Nanosci. Nanotechnol. 2006, 6, 1159-1166. [CrossRef]

20. Liu, Y.; Chen, W.; Wang, S.; Joly, A.G. Investigation of water-soluble x-ray luminescence nanoparticles for photodynamic activation. Appl. Phys. Lett. 2008, 92, 043901. [CrossRef]

21. Zou, X.; Yao, M.; Ma, L.; Hossu, M.; Han, X.; Juzenas, P.; Chen, W. X-ray-induced nanoparticle-based photodynamic therapy of cancer. Nanomedicine 2014, 9, 2339-2351. [CrossRef] [PubMed]

22. Hussain, S.K.; Giang, T.T.H.; Yu, J.S. UV excitation band induced novel Na $\mathrm{Gd}_{2}\left(\mathrm{VO}_{4}\right)_{2}: \mathrm{RE}^{3+}\left(\mathrm{RE}^{3+}=\mathrm{Eu}^{3+}\right.$ or $\mathrm{Dy}^{3+}$ or $\mathrm{Sm}^{3+}$ ) double vanadate phosphors for solid-state lightning applications. J. Alloys Compd. 2018, 739, 218-226. [CrossRef] 
23. Huang, X.; Guo, H. LiCa $\mathrm{MgV}_{3} \mathrm{O}_{12}: \mathrm{Sm}^{3+}$ : A new high-efficiency white-emitting phosphor. Ceram. Int. 2018, 44, 10340-10344. [CrossRef]

24. Duke John David, A.; Muhammad, G.S.; Sivakumar, V. Synthesis and photoluminescence properties of Sm $\mathrm{Sm}^{3+}$

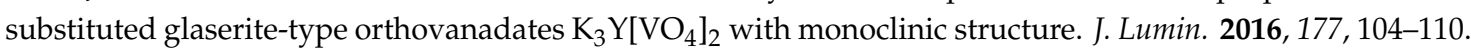
[CrossRef]

25. Kang, F.; Yang, X.; Peng, M.; Wondraczek, L.; Ma, Z.; Zhang, Q.; Qiu, J. Red photoluminescence from Bi ${ }^{3+}$ and the influence of the oxygen-vacancy perturbation in $\mathrm{ScVO}_{4}$ : A combined experimental and theoretical study. J. Phys. Chem. C 2014, 118, 7515-7522. [CrossRef]

26. Yu, M.; Lin, J.; Fang, J. Silica Spheres Coated with $\mathrm{YVO}_{4}$ : $\mathrm{Eu}^{3+}$ Layers via sol-gel process: A simple method to obtain spherical core-shell phosphors. Chem. Mater. 2005, 17, 1783-1791. [CrossRef]

27. Li, K.; Lian, H.; Shang, M.; Lin, J. A novel greenish yellow-orange red $\mathrm{Ba}_{3} \mathrm{Y}_{4} \mathrm{O}_{9}: \mathrm{Bi}^{3+}, \mathrm{Eu}^{3+}$ phosphor with efficient energy transfer for UV-LEDs. Dalton Trans. 2015, 44, 20542-20550. [CrossRef]

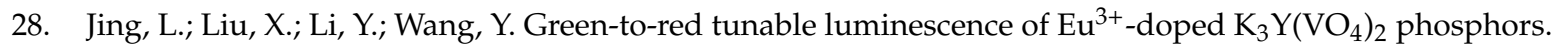
J. Mater. Sci. 2016, 51, 903-910. [CrossRef]

29. Zhao, J.; Guo, C.; Li, T.; Su, X.; Zhang, N.; Chen, J. Synthesis, electronic structure and photoluminescence properties of $\mathrm{Ba}_{2} \mathrm{BiV}_{3} \mathrm{O}_{11}$ : $\mathrm{Eu}^{3+}$ red phosphor. Dyes Pigments 2016, 132, 159-166. [CrossRef]

30. Biswas, P.; Kumar, V.; Agarwal, G.; Ntwaeaborwa, O.; Swart, H. NaSrVO 4 : Sm ${ }^{3+}$-An n-UV convertible phosphor to fill the quantum efficiency gap for LED applications. Ceram. Int. 2016, 42, 2317-2323. [CrossRef]

31. Nakajima, T.; Isobe, M.; Tsuchiya, T.; Ueda, Y.; Manabe, T. Correlation between luminescence quantum efficiency and structural properties of vanadate phosphors with chained, dimerized, and isolated $\mathrm{VO}_{4}$ tetrahedra. J. Phys. Chem. C 2010, 114, 5160-5167. [CrossRef]

32. Huang, Y.; Yu, Y.M.; Tsuboi, T.; Seo, H.J. Novel yellow-emitting phosphors of $\mathrm{Ca}_{5} \mathrm{M}_{4}\left(\mathrm{VO}_{4}\right)_{6}(\mathrm{M}=\mathrm{Mg}, \mathrm{Zn})$ with isolated $\mathrm{VO}_{4}$ tetrahedra. Opt. Express 2012, 20, 4360-4368. [CrossRef] [PubMed]

33. Wang, Y.; Townsend, P.D. Potential problems in collection and data processing of luminescence signals. J. Lumin. 2013, 142, 202-211. [CrossRef]

34. Zhang, G.; Zhao, L.; Fan, F.; Bai, Y.; Ouyang, B.; Chen, W.; Li, Y.; Huang, L. Near UV-pumped yellow-emitting $\mathrm{Ca}_{3} \mathrm{TeO}_{6}: \mathrm{Dy}^{3+}$ phosphor for white light-emitting diodes. Spectrochim. Acta A Mol. Biomol. Spectrosc. 2019, 223, 117343. [CrossRef] [PubMed]

35. Zheng, T.; Ye, S.; Wang, D.; Li, K.; Wang, Y.; Liu, Z.; Wang, H. Surface modification of $\mathrm{SrAl}_{2} \mathrm{O}_{4}: \mathrm{Eu}^{2+}, \mathrm{Dy}^{3+}$ and $\mathrm{Sr}_{4} \mathrm{Al}_{14} \mathrm{O}_{25}: \mathrm{Eu}^{2+}, \mathrm{Dy}^{3+}$ long lasting phosphors and their application in water-borne paint. J. Chin. Ceram. Soc 2015, 2, 17-23.

36. Li, K.; Zhang, Y.; Li, X.; Shang, M.; Lian, H.; Lin, J. Host-sensitized luminescence in $\mathrm{LaNbO}_{4}: \mathrm{Ln}^{3+}$ $\left(\mathrm{Ln}^{3+}=\mathrm{Eu}^{3+} / \mathrm{Tb}^{3+} / \mathrm{Dy}^{3+}\right)$ with different emission colors. Phys. Chem. Chem. Phys. 2015, 17, 4283-4292. [CrossRef] [PubMed]

37. Xia, Z.; Zhou, J.; Mao, Z. Near UV-pumped green-emitting $\mathrm{Na}_{3}(\mathrm{Y}, \mathrm{Sc}) \mathrm{Si}_{3} \mathrm{O}_{9}: \mathrm{Eu}^{2+}$ phosphor for white-emitting diodes. J. Mater. Chem. C 2013, 1, 5917-5924. [CrossRef]

38. Xia, Z.; Zhang, Y.; Molokeev, M.S.; Atuchin, V.V. Structural and luminescence properties of yellow-emitting $\mathrm{NaScSi}_{2} \mathrm{O}_{6}: \mathrm{Eu}^{2+}$ phosphors: $\mathrm{Eu}^{2+}$ site preference analysis and generation of red emission by codoping $\mathrm{Mn}^{2+}$ for white-light-emitting diode applications. J. Phys. Chem. C 2013, 117, 20847-20854. [CrossRef]

39. Lakshmi Devi, L.; Jayasankar, C.K. Spectroscopic investigations on high efficiency deep red-emitting $\mathrm{Ca}_{2} \mathrm{SiO}_{4}: \mathrm{Eu}^{3+}$ phosphors synthesized from agricultural waste. Ceram. Int. 2018, 44, 14063-14069. [CrossRef]

40. Nakano, H.; Kamimoto, K.; Yokoyama, N.; Fukuda, K. The Effect of Heat Treatment on the Emission Color of P-Doped $\mathrm{Ca}_{2} \mathrm{SiO}_{4}$ Phosphor. Materials 2017, 10, 1000. [CrossRef]

41. Rojas-Hernandez, R.E.; Rubio-Marcos, F.; Serrano, A.; Salas, E.; Hussainova, I.; Fernandez, J.F. Towards Blue Long-Lasting Luminescence of Eu/Nd-Doped Calcium-Aluminate Nanostructured Platelets via the Molten Salt Route. Nanomaterials 2019, 9, 1473. [CrossRef] [PubMed]

42. Li, P.; Yang, Z.; Wang, Z.; Guo, Q. White-light-emitting diodes of UV-based $\mathrm{Sr}_{3} \mathrm{Y}_{2}\left(\mathrm{BO}_{3}\right)_{4}: \mathrm{Dy}^{3+}$ and luminescent properties. Mater. Lett. 2008, 62, 1455-1457. [CrossRef]

43. Song, M.; Liu, Y.; Liu, Y.; Wang, L.; Zhang, N.; Wang, X.; Huang, Z.; Ji, C. Sol-gel synthesis and luminescent properties of a novel $\mathrm{KBaY}\left(\mathrm{MoO}_{4}\right)_{3}: \mathrm{Dy}^{3+}$ phosphor for white light emission. J. Lumin. 2019, 211, 218-226. [CrossRef] 
44. Rao, B.V.; Jang, K.; Lee, H.S.; Yi, S.-S.; Jeong, J.-H. Synthesis and photoluminescence characterization of RE ${ }^{3+}$ $\left(=\mathrm{Eu}^{3+}, \mathrm{Dy}^{3+}\right)$-activated $\mathrm{Ca}_{3} \mathrm{La}\left(\mathrm{VO}_{4}\right)_{3}$ phosphors for white light-emitting diodes. J. Alloys Compd. 2010, 496, 251-255. [CrossRef]

45. Ratnam, B.V.; Jayasimhadri, M.; Jang, K.; Sueb Lee, H.; Yi, S.-S.; Jeong, J.-H. White Light Emission from $\mathrm{NaCaPO}_{4}: \mathrm{Dy}^{3+}$ Phosphor for Ultraviolet-Based White Light-Emitting Diodes. J. Am. Ceram. Soc. 2010, 93, 3857-3861. [CrossRef]

46. Rojas-Hernandez, R.E.; Barradas, N.P.; Alves, E.; Santos, L.F.; Almeida, R.M. Up-conversion emission of aluminosilicate and titania films doped with $\mathrm{Er}^{3+} / \mathrm{Yb}^{3+}$ by ion implantation and sol-gel solution doping. Surf. Coat. Technol. 2018, 355, 162-168. [CrossRef]

Sample Availability: Samples of the compounds are available from the authors.

(C) 2020 by the authors. Licensee MDPI, Basel, Switzerland. This article is an open access article distributed under the terms and conditions of the Creative Commons Attribution (CC BY) license (http://creativecommons.org/licenses/by/4.0/). 